\title{
EVALUASI SISTEM PEMBELAJARAN (Menelaah Landasan Filosofis Evaluasi Pembelajaran dalam Perspektif Pengembangan Keilmuan di STAIN Kudus)
}

Mas'udi

Dosen Jurusan Tarbiyah STAIN Kudus

\begin{abstract}
In the process of development, learning system applied at STAIN Kudus is fully geared to the transformation towards the archetypes that have been constituted. In the constitution of science that will be developed, the Islamic perspective on Transformative is the bedrock of scientific development which is formulated.

Based on some of the policies that have been formulated by the government, the process of defining the curriculum in an institution is required to have its application into the system that has been set. In this case, the application of curriculum system applied by STAIN Kudus have it's completely to the provisions of the governance system that has been set.

From the formulation of this research can be revealed that the philosophical foundation of evaluation developed at STAIN Kudus designed completely rely upon the Principal Scientific Pattern set. Transformation effort from text to context, the individual to the social, from the theoretical to the practical area became the basis locomotive for STAIN Kudus curriculum development.
\end{abstract}

Keywords: Evaluation, Learning, Curriculum, Principal Scientific Pattern, Philosophical

\section{A. Latar Belakang}

Salah satu peran guru sebagai evaluator perlu memiliki keterampilan dalam menilai anak didik secara objektif, continue, dan komprehensif. Seorang guru harus melakukan evaluasi pada anak didiknya. Dalam mengevaluasi setiap guru sebagai pengarah pendidikan 
perlu memperhatikan bagaimana teknik-teknik dan prosedur dalam dunia pendidikan sehingga tujuan dan fungsi evaluasi yang diharapkan dapat tercapai. Langkah-langkah dalam mengevaluasi seorang anak atau sekelompok anak perlu adanya perencanaan, pengumpulan data, penilaian data, pengolahan data dan penafsiran data yang telah dikumpulkan sehingga dapat mengambil keputusan untuk dapat melaporkan kepada lembaga pendidikan, orang tua dan masyarakat tentang kemajuan peserta didik masing-masing.

Mengedepankan prinsip-prinsip dasar pembentukan evaluasi efektif bagi para siswa, setiap pelaku pendidikan harus mampu menghadirkan mutu kurikulum yang mengarahkan. Hal ini bersandar kepada hakikat kurikulum sebagai bagian penting dalam pertumbuhan proses pembelajaran. Kesuksesan pembelajaran bergantung sepenuhnya dengan aspek-aspek positif muatan kurikulum yang ditawarkan pada satuan pendidikan yang diterapkan. Menyikapi kondisi ini, berbagai tawaran sistem pembelajaran yang diberikan kepada pemerintah tertanggung dengan nilai jual yang bisa diambil manfaatnya oleh masyarakat. Berbagai sistem pembelajaran yang muncul senantiasa dipertaruhkan berdasar kepada rate of return nilai tambah yang bisa diterima oleh masyarakat untuk masa depan kehidupan mereka.

Berbagai pengembangan yang ditawarkan dalam susunan pembelajaran di berbagai instansi pendidikan tak mungkin dilepaskan di dalamnya perwujudan evaluasi guna mencapai nilai-nilai terbaik harapan institusi tersebut. Berdasar kepada alasan di atas maka menjadi sebuah keniscayaan yang tidak mungkin dinafikan bahwa konstruk pembelajaran yang telah berjalan di suatu lembaga pendidikan akan senantiasa dipertaruhkan kredibilitasnya demi kemapanan peserta didik di masa yang akan datang. Menyikapi tentang hal ini, Pemerintah Republik Indonesia secara utuh mengemukakan rumusan Standar Pendidikan Nasional yang harus dikukuhkan dalam perumusan kurikulum pasca perwujudan evaluasi. Dalam menyikapi hal ini, Peraturan Pemerintah Republik Indonesia Nomor 19 Tahun 2005 tentang Standar Nasional Pendidikan Pasal 1 No. 14-15, dapat dijadikan preferensi bahwa "Kurikulum adalah seperangkat rencana dan pengaturan mengenai tujuan, isi, dan bahan pelajaran serta cara yang digunakan sebagai pedoman penyelenggaraan kegiatan pembelajaran untuk mencapai 
tujuan pendidikan tertentu." Pada bagian selanjutnya juga dirumuskan bahwa "Kerangka dasar kurikulum adalah rambu-rambu yang ditetapkan dalam Peraturan Pemerintah ini untuk dijadikan pedoman dalam penyusunan kurikulum tingkat satuan pendidikan dan silabusnya pada setiap satuan pendidikan. Kurikulum tingkat satuan pendidikan adalah kurikulum operasional yang disusun oleh dan dilaksanakan di masingmasing satuan pendidikan."

Rumusan kurikulum sebagai rambu utama pola pembelajaran di dalam dunia pendidikan mengisyaratkan secara utuh bahwa kenyataannya akan memandu gerak pembelajaran ke arah yang lebih positif bagi segenap pelaku pendidikan. Kenyataan ini secara niscaya tidak dibenarkan keberadaannya ketika kurikulum hanya dihadirkan sebagai pedoman pembelajaran tanpa adanya evaluasi yang mengarahkan atas keberadaannya. Evaluasi sebagai barometer utama untuk melihat efektivitas suatu pembelajaran menjadi nilai dasar lembaga pendidikan guna menghadirkan mutu kurikulum yang bermanfaat.

Sepintas lalu, menganalisa secara deskriptif konseptual pada rumusan di atas dapatlah dirumuskan bahwa evaluasi adalah proses mendeskripsikan, mengumpulkan dan menyajikan suatu informasi yang bermanfaat untuk pertimbangan dalam pengambilan keputusan. Evaluasi pembelajaran merupakan evaluasi dalam bidang pembelajaran. Tujuan evaluasi pembelajaran adalah untuk menghimpun informasi yang dijadikan dasar untuk mengetahui taraf kemajuan, perkembangan, dan pencapaian belajar siswa, serta keefektifan pengajaran guru. Dalam pernyataan ini juga ditegaskan bahwa evaluasi pembelajaran mencakup kegiatan pengukuran dan penilaian. Bila ditinjau dari tujuannya, evaluasi pembelajaran dibedakan atas evaluasi diagnostik, selektif, penempatan, formatif, dan sumatif. Bila ditinjau dari sasarannya, evaluasi pembelajaran dapat dibedakan atas evaluasi konteks, input, proses, hasil dan outcome. Proses evaluasi dilakukan melalui tiga tahap yaitu tahap perencanaan, pelaksanaan, pengolahan hasil dan pelaporan. ${ }^{1}$

Deskripsi argumentatif yang telah dipaparkan pada pernyataan di atas menunjuk kepada hakikat dari evaluasi yang mengisi di dalamnya berbagai aktivitas menanyakan eksepsi atas pola-pola pembelajaran

1 Baca; Evaluasi Pembelajaran dalam http://www.artikelbagus.com/2012/03/ evaluasi-pembelajaran.html (Diakses tanggal, 22 September 2013) 
yang telah berjalan. Dalam makna yang lain pula dapat dijelaskan bahwa evaluasi juga dapat diartikan sebagai suatu kegiatan yang terencana untuk mengetahui keadaan suatu objek dengan menggunakan instrumen dan hasilnya dibandingkan dengan suatu tolak ukur untuk memperoleh suatu kesimpulan. Bersandar kepada eksistensi evaluasi, sistem pembelajaran yang dijalankan akan menjadi semakin kontributif terhadap kebutuhan-kebutuhan desain pembelajaran yang dibangun.

Pada aspek pembidangannya, fungsi utama evaluasi bertujuan kepada telaah suatu objek atau keadaan untuk mendapatkan informasi yang tepat sebagai dasar untuk pengambilan keputusan. Penjelasan ini sebagaimana dinyatakan oleh Grondlund dan Linn yang menegaskan bahwa evaluasi pembelajaran adalah suatu proses mengumpulkan, menganalisis dan menginterpretasi informasi secara sistematik untuk menetapkan sejauh mana ketercapaian tujuan pembelajaran. ${ }^{2}$ Untuk memperoleh informasi yang tepat dalam kegiatan pembelajaran evaluasi dilakukan melalui kegiatan pengukuran. Pengukuran merupakan suatu proses pemberian skor atau angka-angka terhadap suatu keadaan atau gejala berdasarkan aturan-aturan tertentu. Dengan demikian terdapat kaitan yang erat antara pengukuran (measurement) dan evaluasi (evaluation) pada kegiatan dasar dalam evaluasi.

Berpijak kepada berbagai analisa yang telah mengemuka pada beberapa rumusan penjelasan di atas, tampak bahwa evaluasi pada dasarnya adalah usaha untuk melakukan pengukuran baik di tingkat perilaku ataupun intelegensi siswa untuk mengungkapkan perbedaan individual maupun kelompok. Dalam hal ini pula, Rusman menjelaskan bahwa hasil evaluasi dapat digunakan terutama untuk keperluan seleksi siswa, bimbingan pendidikan, dan perbandingan efektivitas antara dua atau lebih program/metode pendidikan. Secara deskriptif pula Rusman mengukuhkan bahwa objek evaluasi dititikberatkan pada hasil belajar terutama dalam aspek kognitif dan khususnya yang dapat diukur dengan alat evaluasi yang objektif dan dapat dibakukan. Jenis data yang dikumpulkan dalam evaluasi adalah data objektif khususnya skor hasil tes. $^{3}$

Mengukur skala kemampuan siswa melalui evaluasi adalah

3 Rusman, Manajemen Kurikulum (Jakarta: Rajagrafindo Persada, 2012), hlm. 114. 
langkah positif untuk melihat hasil hakiki dari penerapan unsur-unsur pendidikan yang dilakukan. Fakta ini harus disadari sepenuhnya oleh para pelaku pendidikan demi mewujudkan struktur pendidikan yang mengarahkan kepada keberhasilan siswa di masa yang akan datang. Segenap pelaku pendidikan niscaya memahami bahwa konstruk pendidikan ideal sebelum menerapkan aspek-aspek evaluasi dalam pembelajaran adalah pengetahuan mereka tentang rencana pendidikan itu sendiri. Haruslah dipahami pula bahwa pendahuluan dari semua perencanaan ini sendiri juga akan dipersandingkan dengan evaluasi terhadap kenyataannya. Melihat kondisi inilah Matin menjelaskan bahwa evaluasi rencana pendidikan tercakup pada dirinya beberapa tujuan khusus. Di antaranya; a) usaha menemukan adanya kelemahankelemahan dalam tahap perencanaan, seperti sasaran yang tidak realistis, biaya tidak memadai, alokasi kegiatan per tahun tidak cocok, dan sebagainya yang kesemuanya ini membutuhkan revisi (perbaikan) agar ada keseimbangan kegiatan pada tahap pelaksanaan rencana; b) evaluasi dilakukan untuk mewujudkan diagnosa terhadap setiap mata rantai kegiatan proses perencanaan dan memberikan dasar-dasar bagi penyusunan kembali rencana yang sudah dibuat. Oleh karena itu, siklus kegiatan penyusunan rencana pendidikan harus diulangi kembali dari awal meskipun terjadi perubahan rencana yang sedang dilaksanakan, namun proses perencanaan pendidikan harus dapat berjalan terus tanpa berhenti di tengah jalan; c) evaluasi juga dimaksudkan untuk melihat sumbangan atau pengaruh kegiatan yang sudah dilakukan. Misalnya, apakah ada pengaruh proyek penataran guru terhadap kemajuan belajar siswa di kelas, dan apakah ada pengaruh penambahan sekolah atau penambahan ruang kelas terhadap pemerataan kesempatan belajar anak di sekolah. ${ }^{4}$

Usaha-usaha positif terhadap pemenuhan nilai-nilai dasar dalam pendidikan secara niscaya dilakukan oleh pemerintah yang hakikatnya juga perlu diwujudkan di tingkat Satuan Kerja (SATKER) Pendidikan. Untuk itulah, mengamati kondisi ini Mas'udi ${ }^{5}$ membenarkan bahwa

4 Matin, Dasar-dasar Perencanaan Pendidikan (Jakarta: Rajagrafindo Persada, 2013), hlm. 116-117.

5 Deskripsi ini dikupas Mas'udi dalam rancangan penelitiannya pada pembahasan tentang Desain Kurikulum STAIN Kudus (Studi Analisis Mata Kuliah: Filsafat Dakwah, Pekerjaan Sosial, Antropologi, Antropologi Agama, dan Metodologi Penelitian Filsafat). Lebih lanjut baca; Mas'udi, Desain Kurikulum STAIN Kudus (Studi Analisis Mata Kuliah: Filsafat 
dalam orientasi rancangan pemenuhan beberapa hal di atas pemerintah mewadahinya melalui Peraturan Pemerintah Nomor 19 Tahun 2005 tentang Standar Pendidikan Nasional. Pada analisa tentang Standar Nasional Pendidikan (SNP) pemerintah menguatkan pentingnya analisa kesadaran pelaku pendidikan terhadap lingkup pokok SNP dimaksud. Beberapa cakupan SNP yang niscaya disadari oleh para pelaku pendidikan adalah, pertama; "Standar Isi". Standar Isi sendiri merupakan ruang lingkup materi dan tingkat kompetensi yang dituangkan dalam kriteria tentang kompetensi tamatan, kompetensi bahan kajian, kompetensi mata pelajaran, dan silabus pembelajaran yang harus dipenuhi oleh peserta didik pada jenjang dan jenis pendidikan tertentu. Cakupan kedua yang harus diperhatikan oleh pelaku pendidikan adalah "Standar Proses". Standar Proses adalah standar nasional pendidikan yang berkaitan dengan pelaksanaan pembelajaran pada satu satuan pendidikan untuk mencapai standar kompetensi lulusan. Cakupan berikutnya yang harus diwujudkan dalam pengukuhan SNP adalah "Standar Kompetensi Lulusan". Maksud dari cakupan ini adalah keniscayaan untuk menguatkan kualifikasi kemampuan lulusan yang mencakup sikap, pengetahuan, dan keterampilan. Selanjutnya, pada cakupan keempat, dituntut sepenuhnya hadir pada Standar Nasional Pendidikan (SNP) "Standar Pendidik dan Tenaga Kependidikan". Maksud utama dari penjabaran ini adalah keniscayaan untuk menguatkan kriteria pendidikan prajabatan dan kelayakan fisik maupun mental, serta pendidikan dalam jabatan. Cakupan berikut yang harus terwujud dalam Standar Nasional Pendidikan adalah "Standar Sarana dan Prasarana", yaitu standar nasional pendidikan yang berkaitan dengan kriteria minimal tentang ruang belajar, tempat berolahraga, tempat beribadah, perpustakaan, laboratorium, bengkel kerja, tempat bermain, tempat berkreasi dan berekreasi, serta sumber belajar lain, yang diperlukan untuk menunjang proses pembelajaran, termasuk penggunaan teknologi informasi dan komunikasi. Sementara bagian lain yang harus tercakup juga adalah "Standar Pengelolaan", yaitu standar nasional pendidikan yang berkaitan dengan perencanaan, pelaksanaan, dan pengawasan kegiatan pendidikan pada tingkat satuan pendidikan, kabupaten/kota, provinsi, atau nasional agar tercapai efisiensi dan efektivitas penyelenggaraan pendidikan. Bagian akhir dari 
cakupan SNP yang harus ada adalah "Standar Pembiayaan", yaitu standar yang mengatur komponen dan besarnya biaya operasi satuan pendidikan yang berlaku selama satu tahun; dan "Standar Penilaian Pendidikan", yakni standar nasional pendidikan yang berkaitan dengan mekanisme, prosedur, dan instrumen penilaian hasil belajar peserta didik.

Berangkat dari lingkup Standar Nasional Pendidikan (SNP) sebagaimana dijelaskan pada pembahasan di atas, tampak berdiri dengan kuat satuan orientasi pendidikan nasional yang mengikat semua unsur termaktub pada diri pelaku pendidikan. Cakupan yang telah terdeskripsikan pada pembahasan di atas menggiring segenap stakeholders dalam pendidikan untuk senantiasa mengingat unsurunsur termaktub demi tercapainya mutu pendidikan yang baik serta mengarahkan. Hal ini dapat dilihat pula pada tuntutan adanya pemenuhan standar isi dalam Peraturan Pemerintah Nomor. 19 Tahun 2005. Dalam Pasal 5 mengenai tuntutan pemenuhan Standar Isi dijelaskan bahwa (1) Standar isi mencakup lingkup materi dan tingkat kompetensi lulusan pada jenjang dan jenis pendidikan tertentu. Pada bagian kedua dijelaskan bahwa standar isi sebagaimana dimaksud pada ayat (1) memuat kerangka dasar dan struktur kurikulum, beban belajar, kurikulum tingkat satuan pendidikan, dan kalender pendidikan/ akademik.

Berbagai penjelasan yang tercakup pada pemenuhan nilainilai Standar Nasional Pendidikan sebagaimana terdeskripsikan pada beberapa pembahasan di atas menunjukkan dinamika yang akan muncul terhadap pencapaian mutu terbaik dalam pendidikan. Akan tetapi, keanekaragaman kondisi yang mengitari kondisi utama realitas pendidikan mustahil menafikan berbagai polemik yang akan muncul. Hal ini senada dengan argumentasi Zamroni yang menyatakan bahwa pendidikan merupakan suatu proses yang sangat kompleks dan berjangka panjang. Berbagai aspek yang tercakup dalam proses tersebut berkaitan erat antara satu sama lain dan bermuara pada terwujudnya manusia yang memiliki nilai hidup, pengetahuan hidup, dan keterampilan hidup. Kompleksitas tersebut tercipta pula karena interaksi di antara berbagai aspek terkait pendidikan, seperti guru, bahan ajar, fasilitas, kondisi siswa, kondisi lingkungan, dan metode mengajar yang digunakan tidak selamanya memiliki sifat dan bentuk yang konsisten serta dapat 
dikendalikan. ${ }^{6}$

Untuk selanjutnya, berpijak kepada gambaran kondisional yang telah diberikan kepada masing-masing perguruan tinggi terkait dengan kebijakan internalnya, Sekolah Tinggi Agama Islam Negeri (STAIN) Kudus dalam pengembangan akademik di dalamnya memunculkan beberapa identitas penting pendukung eksistensinya. Hal ini terlihat pada Pola Ilmiah Pokok (PIP) Sekolah Tinggi Agama Islam Negeri (STAIN) Kudus yang mendukung kepada tercapainya realitas Islam Transformatif. Di antara beberapa PIP yang dirancang eksistensinya pada STAIN Kudus adalah membumikan nilai-nilai keislaman, dengan mengembangkan keilmuan Islam yang transformatif, mengedepankan perubahan dari teks ke dalam konteks, perubahan dari pemikiran ke dalam aksi, dan perubahan dari individu ke dalam kehidupan sosial. Visi, misi, tujuan dan PIP tersebut bercita-cita ingin menjadikan STAIN Kudus sebagai motor penggerak perubahan dari masyarakat berkembang menuju masyarakat religius yang modern. Pembentukan masyarakat religius yang modern selalu diikuti oleh proses transformasi sosial, yang menandai suatu perubahan dari masyarakat yang potensi keberagamaannya kurang berkembang menuju masyarakat maju yang dapat mengaktualisasikan potensi keberagamaannya secara optimal dalam konteks masyarakat multikultural. ${ }^{7}$

Segenap Stakeholder STAIN Kudus menyadari bahwa di era global sekarang ini, transformasi itu berjalan dengan sangat cepat yang kemudian mengantarkan pada masyarakat berbasis pengetahuan (knowledge based society). Di dalam masyarakat berbasis pengetahuan, peranan ilmu pengetahuan dan teknologi sangat dominan. Dalam analisis internalnya, STAIN Kudus memperjelas kondisi riil masyarakat wilayah Pantura Jawa Tengah Bagian Timur yang pada umumnya indeks teknologi penguasaan mereka masih rendah dan belum secara optimal memanfaatkan Iptek sebagai penggerak utama (prime mover) perubahan masyarakat. Oleh karena itu STAIN Kudus memfasilitasi peningkatan indeks teknologi tersebut, dengan menggeser dan mengembangkan keilmuan Islam yang bukan hanya sebuah ajaran yang berada di dalam diri (saleh individual), melainkan ajaran yang integral menyatu di luar

6 Zamroni, Paradigma Pendidikan Masa Depan (Yogyakarta: Bigraf Publishing, 2000), hlm. 128.

7 Renstra dan Renop STAIN Kudus 2004-2014, hlm. 11. 
diri (saleh sosial) dengan arus kesadaran diri dan denyut kehidupan masyarakat yang multikultural, serta bermanfaat bagi seluruh kehidupan manusia, tanpa membedakan golongan, etnis dan agama. Di samping kondisi tersebut, STAIN Kudus juga berupaya penuh melakukan transfer teknologi yang biasanya terjadi melalui investasi sumber daya manusia (human investment). Dengan demikian, kebijakan pendidikan di STAIN Kudus dirancang sepenuhnya sejalan dengan kebijakan investasi, yang ditempuh melalui tiga jalur transformasi: 1) Transformasi diri; (transformation of self) terwujudnya tanggung jawab dan pemahaman secara kritis dan reflektif terhadap diri dan orang lain, 2) Transformasi pendidikan (transformation of schools), yang menuntut penalaran kritis terhadap semua aspek pengajaran yang berpusat pada mahasiswa (student centered), dan 3) Transformasi masyarakat (transformation of society), yang secara proaktif mendorong peran serta masyarakat menerapkan dan menumbuhkembangkan kekuatan beragama, nilai keragaman (diversity), keadilan, dan kebersamaan. ${ }^{8}$

Mengkaji beberapa aspek pengembangan yang perlu dilakukan di STAIN Kudus, analisis tentang evaluasi terhadap semua aktivitas akademik yang telah berjalan penting dilakukan. Hal ini secara niscaya mutlak diperlukan karena visi dan misi yang ada dan dikembangkan di STAIN Kudus harus diwujudnyatakan demi menegaskan eksistensi lembaga ini kepada segenap masyarakat. Hasil yang nantinya diwujudkan seyogyanya menjadi catatan berharga bagi segenap stakeholders sehingga pada akhirnya kesesuaian harapan menjadi kebenaran yang diperoleh.

\section{B. Landasan Teoritis Evaluasi Pembelajaran}

Menganalisa tentang konsep evaluasi dalam dunia pembelajaran secara niscaya akan dihadapkan kepada beberapa perspektif bangunan pemikiran yang diberikan oleh para ahli. Meskipun secara eksistensial paradigmatik probabilitas dari pemikiran tersebut beraneka ragam, namun tinjauan pemikirannya niscaya mengarah kepada kesatuan orientasi pemikiran demi tegaknya perumusan tentang kurikulum itu sendiri.

Rusman $^{9}$ dalam penjelasannya tentang evaluasi menegaskan

8 Ibid., hlm. 11.

9 Rumusan pembahasan yang dikemukakan Rusman dalam pembahasan ini 
bahwa terdapat empat rumus deskriptif yang bisa dijadikan pijakan dalam rumusan evaluasi. Adapun keempat rumusan tersebut, pertama; measurement. Konsep measurement dalam evaluasi pembelajaran menunjuk kepada penekanan penting atas objektivitas dalam proses evaluasi. Aspek objektivitas yang ditekankan oleh konsep ini perlu dijadikan landasan yang terus-menerus di dalam rangka mengembangkan konsep dan sistem evaluasi kurikulum. Di samping itu, pendekatan yang digunakan oleh konsep ini masih sangat besar pengaruhnya dan dirasakan faedahnya dalam berbagai kegiatan pendidikan, seperti seleksi dan klasifikasi siswa, pemberian nilai di sekolah, dan kegiatan penelitian pendidikan.

Rumusan kedua yang ditawarkan Rusman adalah congruence. Dalam pandangannya, eksistensi evaluasi dalam suatu pembelajaran pada dasarnya merupakan pemeriksaan kesesuaian atau congruence antara tujuan pendidikan dan hasil belajar yang dicapai, untuk melihat sejauh mana perubahan hasil pendidikan telah terjadi. Hasil evaluasi diperlukan dalam rangka penyempurnaan program, bimbingan pendidikan, dan pemberian informasi kepada pihak-pihak di luar pendidikan. Objek evaluasi dititikberatkan pada hasil belajar dalam bentuk kognitif, psikomotorik, maupun nilai dan sikap. Jenis data yang dikumpulkan adalah data objektif khususnya skor hasil tes. Pengembangan dalam konsep congruence ini menjadi data penghubung antara kegiatan evaluasi dengan tujuan pendidikan untuk mengkaji efektivitas kurikulum yang sedang dikembangkan. Dengan kata lain, konsep congruence ini telah memperlihatkan adanya "high degree of integration with the instructional process". Konsep ketiga dari evaluasi yang dikemukakan oleh Rusman adalah illumination. Konsep ini secara utuh disampaikan sebagai reaksi terhadap konsep measurement dan congruence yang bersifat 'terminal' seperti telah disinggung dalam bagian sebelumnya. Konsep illumination menekankan pentingnya dilakukan evaluasi yang berkelanjutan selama proses pelaksanaan kurikulum sedang berlangsung. Gagasan yang terkandung di dalam konsep ini memang penting dan menunjang proses penyempurnaan kurikulum karena pihak pengembang kurikulum akan memperoleh

sepenuhnya dikupas secara terperinci dalam karya beberapa sub pemikirannya di dalam 
informasi yang cukup terintegrasi sebagai dasar untuk mengoreksi dan menyempurnakan kurikulum yang sedang dikembangkan.

Untuk selanjutnya, pada bagian keempat Rusman menjelaskan bahwa bagian dari evaluasi adalah educational system evaluation. Dalam bagian ini dijelaskan bahwa evaluasi pada dasarnya adalah perbandingan antara performance setiap dimensi program dan kriteria yang akan berakhir dengan suatu deskripsi dan judgement. Hasil evaluasi diperlukan untuk penyempurnaan program dan penyimpulan hasil program secara keseluruhan. Objek evaluasi mencakup input (bahan, rencana, peralatan), proses dan hasil yang dicapai dalam arti yang lebih luas. Jenis data yang dikumpulkan meliputi baik data objektif maupun data subjektif (judgement antara lain data).

Membaca beberapa deskripsi di atas tampak bahwa evaluasi merupakan bagian dari sistem manajemen, yaitu perencanaan, organisasi, pelaksanaan, dan evaluasi. Kurikulum juga dirancang dari tahap perencanaan, organisasi, kemudian pelaksanaan dan akhirnya monitoring dan evaluasi. Secara terperinci pula penjelasan tersebut menjelaskan bahwa evaluasi bertujuan untuk mengumpulkan, menganalisis, dan menyajikan data untuk bahan penentuan keputusan mengenai kurikulum apakah akan direvisi atau diganti.

Banyak catatan secara niscaya diberikan oleh para ahli mengamati eksistensi perwujudan pendidikan dengan komposisi pembelajaran yang diterapkan di tengah-tengah mereka. Hal ini sepenuhnya dapat disandarkan kepada perspektif antropologis bahwa pendidikan merupakan gejala budaya. Untuk itulah, mengamati hal ini menurut para antropolog dijelaskan bahwa pendidikan dapat dimaknai setiap sistem budaya atau instruksi intelektual yang formal atau semi formal. Pendidikan adalah ciri masyarakat manusia yang universal. Walaupun sebagai universalitas kebudayaan, sifat spesifiknya sangat berbeda antara masyarakat yang satu dan masyarakat yang lainnya. ${ }^{10}$

\section{Perencanaan dalam Dunia Pendidikan}

Rumusan tentang evaluasi pendidikan mustahil dihindarkan dari adanya perencanaan dalam pendidikan itu sendiri. Matin menjelaskan hlm. 113.

10 Mahmud dan Suntana, Antropologi Pendidikan (Bandung: Pustaka Setia, 2012), 
bahwa dalam perkembangannya, perencanaan pendidikan telah mewujud sebagai disiplin ilmu atau menjadi cabang ilmu pengetahuan yang baru. Jika dipandang dari sudut ideologi, maka perencanaan pendidikan itu adalah berbeda-beda, dan jika dipandang dari sudut metodologi, maka perencanaan pendidikan bersifat fleksibel yaitu dapat disesuaikan dengan sistem sosial dan taraf perkembangan yang berbeda-beda dari berbagai masyarakat yang ada. Konsep-konsep dan prinsip-prinsip perencanaan pendidikan bersifat universal dan applicable untuk setiap masyarakat. ${ }^{11}$ Fakta ini menjadi suatu asas utama untuk memberikan penjabaran bahwa hakikat evaluatif dalam pendidikan akan bersinergi logis terhadap formulasi-formulasi perencanaan pendidikan yang akan ditawarkan.

Menyimak keterhubungan antara perencanaan pendidikan dan evaluasi yang akan dilakukan di dalamnya penting dimengerti bahwa tugas pokok perencanaan pendidikan adalah menentukan keadaan yang sebaik-baiknya dari hubungan-hubungan internal dan eksternal dalam suatu sistem pendidikan untuk mencapai keseimbangan yang sebaikbaiknya dalam keadaan yang berubah secara dinamis dan mempengaruhi ke arah perubahan yang diinginkan. Dalam rangka pandangan ini maka perencanaan pendidikan menjadi suatu keharusan bagi pembangunan bangsa dan negara. ${ }^{12}$

Perencanaan dan evaluasi dalam dunia pendidikan kenyataan keduanya berkorelasi kuat terhadap pertumbuhan pendidikan itu sendiri. Dalam pertumbuhannya dapat disadari bahwa pendidikan merupakan suatu investasi pembangunan sumber daya manusia yang sangat diperlukan dalam pembangunan sosial dan ekonomi suatu masyarakat dan suatu bangsa. Pendidikan dewasa ini diselenggarakan semakin demokratis, semakin merata dan terbuka bagi setiap orang. Selain itu, pendidikan juga semakin bervariasi dalam tujuan, fungsi, isi, dan metodenya; semakin bervariasi dalam program, bidang studi, dan stratanya; semakin spesifik dalam komponen pendidikan yang bersifat umum dan semakin kaya dalam komponen vokasionalnya; serta semakin bervariasi dalam aspek profesional dan spesialisasinya. Oleh sebab itu, pendidikan semakin banyak memerlukan berbagai keahlian profesional

11 Matin, Perencanaan Pendidikan-Perspektif Proses dan Teknik dalam Penyusunan Rencana Pendidikan (Jakarta: Rajagrafindo Persada, 2013), hlm. 1.

12 Ibid., hlm. 2. 
dalam sistem manajemennya serta memerlukan berbagai keahlian yang bersifat interdisipliner dalam memecahkan masalahnya. ${ }^{13}$

Sistem pendidikan telah dipandang sebagai suatu fungsi yang melekat pada kehidupan manusia. Dalam kaitan ini, Matin mengutip Amidjaya dari Endang Sunarya menjelaskan bahwa sistem pendidikan merupakan salah satu lembaga sosial tertua yang selalu mengalami berbagai dampak perubahan yang terjadi di dalam masyarakat. Pendapat ini dipertegas juga oleh Matin dari Hassan dalam Endang Sunarya bahwa sejarah peradaban menunjukkan betapa perubahan dari suatu kondisi lama ke kondisi baru terus terjadi sebagai suatu proses yang sangat menyadarkan manusia, dan bahwa realitas masa kini merupakan landasan untuk masa depan. ${ }^{14}$

\section{Visi Pendidikan}

Menjelaskan tentang visi pendidikan sebagai eksepsi terhadap peneguhan mutu pendidikan Moch. Idochi Anwar menegaskan dalam karya yang dikutipnya dari Salusu dengan bacaan terhadap karya Helgeson bahwa visi adalah penjelasan mengenai rupa yang seharusnya dari suatu organisasi kalau ia berjalan dengan baik. Pada bagian definisi lain Moch. Idochi Anwar menyatakan bahwa visi atau wawasan adalah suatu pandangan yang merupakan kristalisasi dan intisari dari suatu kemampuan (competence), kebolehan (ability), dan kebiasaan (self efficacy) dalam melihat, menganalisis, dan menafsirkan. Definisi ini dikukuhkan oleh Moh. Idochi Anwar dengan kesesuaiannya terhadap penjelasan Sanusi yang menjelaskan bahwa visi atau wawasan adalah penglihatan yang mendalam, mengandung pengetahuan (kognitif), kecintaan (afektif), dan kepedulian terhadap profesi serta kemampuan (konatif). ${ }^{15}$

Untuk selanjutnya, bahasan tentang visi dalam pendidikan patutlah kiranya menyinambungkan keadaannya dengan perspektif pendidikan dibangun. Nanang Martono menjelaskan bahwa perspektif ibarat jendela dalam sebuah rumah. Melalui jendela setiap pribadi dapat melihat objek yang berada di luar rumah. Pemandangan dari satu

13 Matin, Dasar-dasar Perencanaan Pendidikan..., hlm. 1.

14 Ibid., hlm. 4-5.

15 Moh. Idochi Anwar, Administrasi Pendidikan dan Manajemen Biaya Pendidikan (Jakarta: Rajagrafindo Persada, 2013), hlm.25. 
jendela ke jendela yang lain akan menghasilkan tampilan yang berbeda. Bersandar kepada kenyataan inilah Durkheim dalam Nanang Martono melihat bahwa fungsi utama pendidikan adalah mentransmisikan nilainilai dan norma-norma dalam masyarakat. Durkheim dalam Nanang Martono berargumen bahwa; Society can survive only if there exists among members a sufficient degree of homogeneity; education perpectuates and reinforces this homogeneity by fixing in the child from the beginning the essential similarities which collective life demands. ${ }^{16}$

Secara hakiki, beberapa pemikiran pendidikan yang disampaikan oleh Durkheim sepenuhnya mengarah kepada pentingnya menghadirkan prinsip-prinsip moralitas dalam visi pendidikan. Dalam ketegasan pemikiran pendidikannya Durkheim menjelaskan bahwa pendidik yang akan melakukan rasionalisasi pendidikan tetapi tidak bias memperkirakan arah pengembangan sentimen baru tidak siap menghadapi perkembangan kepribadian siswa dalam pendidikan. Untuk itulah, ketidakmampuan pendidik mengarahkan semua realitas tersebut akan menjadikan dirinya gagal dalam tugas pendidikan yang dilakukan. ${ }^{17}$

Rumusan tentang visi pendidikan secara nyata mengisyarat kepada perlunya meneguhkan tujuan dari pendidikan itu sendiri. Tujuan pendidikan harus diarahkan untuk menjelaskan kaitan masa kini dengan masa depan bersandar kepada norma yang dikehendaki atau yang diinginkan dalam pendidikan. Hal ini pula berkorelasi positif terhadap rumusan dan filosofi yang dibangun oleh setiap pribadi tentang hakikat manusia. Pemahaman akan kenyataan ini secara nyata akan menentukan materi yang tepat untuk kegiatan pendidikan. ${ }^{18}$

16 Lebih lanjut baca; Nanang Martono, Kekerasan Simbolik di Sekolah-Sebuah Ide Sosiologi Pendidikan Pierre Bourdieu -(Jakarta: Rajagrafindo Persada, 2012), hlm. 13-16.

17 Emile Durkheim, Pendidikan Moral-Suatu Studi Teori dan Aplikasi Sosiologi Pendidikan-(Jakarta: Erlangga, 1990), hlm. 9.

18 Moh. Idochi Anwar, Administrasi Pendidikan dan Manajemen Biaya Pendidikan hlm. 42 . 


\section{DAFTAR PUSTAKA}

Emile Durkheim, Pendidikan Moral-Suatu Studi Teori dan Aplikasi Sosiologi Pendidikan-. Jakarta: Erlangga, 1990.

Evaluasi Pembelajaran dalam http://www.artikelbagus.com/2012/03/evaluasipembelajaran.html (Diakses tanggal, 22 September 2013)

Mahmud dan Suntana, Antropologi Pendidikan. Bandung: Pustaka Setia, 2012.

Mas'udi, dalam rancangan penelitiannya pada pembahasan tentang Desain Kurikulum STAIN Kudus (Studi Analisis Mata Kuliah: Filsafat Dakwah, Pekerjaan Sosial, Antropologi, Antropologi Agama, dan Metodologi Penelitian Filsafat). Lebih lanjut baca; Mas'udi, Desain Kurikulum STAIN Kudus (Studi Analisis Mata Kuliah: Filsafat Dakwah, Pekerjaan Sosial, Antropologi, Antropologi Agama, dan Metodologi Penelitian Filsafat). Kudus: STAIN Kudus, 2013.

Matin, Dasar-dasar Perencanaan Pendidikan. Jakarta: Rajagrafindo Persada, 2013.

Moh. Idochi Anwar, Administrasi Pendidikan dan Manajemen Biaya Pendidikan. Jakarta: Rajagrafindo Persada, 2013.

Nanang Martono, Kekerasan Simbolik di Sekolah-Sebuah Ide Sosiologi Pendidikan Pierre Bourdieu-. Jakarta: Rajagrafindo Persada, 2012.

Renstra dan Renop STAIN Kudus 2004-2014.

Rusman, Manajemen Kurikulum. Jakarta: Rajagrafindo Persada, 2012.

Zamroni, Paradigma Pendidikan Masa Depan. Yogyakarta: Bigraf Publishing, 2000. 